\title{
Experimental and Theoretical Study of Microturbine-Based BCHP System*
}

By

P. D. Fairchild

S. D. Labinov

A. Zaltash

B. D. T. Rizy

Buildings Technology Center

Energy Division

Oak Ridge National Laboratory

Oak Ridge, Tennessee 37831-6070

Invited Presentation/Publication for:

2001 ASME International Congress and Exposition

November 11-16, 2001

New York, New York

*Oak Ridge National Laboratory, managed by UT-Battelle, LLC, for the U.S. Department of Energy under contract DE-AC05-00OR22725.

The submitted manuscript has been authored by a contractor of the U.S. government under contract DEAC05-000R22725. Accordingly, the U.S. Government retains a nonexclusive, royalty-free license to publish or reproduce the published form of this contribution, or allow others to do so, for U.S. Government purposes. 


\title{
EXPERIMENTAL AND THEORETICAL STUDY OF MICROTURBINE-BASED BCHP SYSTEM
}

\author{
P. D. Fairchild \\ S. D. Labinov \\ A. Zaltash \\ D. T. Rizy \\ Buildings Technology Center \\ Energy Division \\ Oak Ridge National Laboratory \\ Oak Ridge, Tennessee
}

\section{ABSTRACT}

On-site and near-site distributed power generation (DG), as part of a Buildings Cooling, Heating and Power (BCHP) system, brings both electricity and waste heat from the DG sources closer to the end user's electric and thermal loads. Consequently, the waste heat can be used as input power for heat-activated air conditioners, chillers, and desiccant dehumidification systems; to generate steam for space heating; or to provide hot water for laundry, kitchen, cleaning services and/or restrooms. By making use of what is normally waste heat, $\mathrm{BCHP}$ systems meet a building's electrical and thermal loads with a lower input of fossil fuel, yielding resource efficiencies of 40 to $70 \%$ or more.

To ensure the success of BCHP systems, interactions of a DG system-such as a microturbine and thermal heat recovery units under steady-state modes of operation with various exhaust backpressures-must be considered. This article studies the performance and emissions of a $30-\mathrm{kW}$ microturbine over a range of design and off-design conditions in steady-state operating mode with various backpressures. In parallel with the experimental part of the project, a BCHP mathematical model was developed describing basic thermodynamic and hydraulic processes in the system, heat and material balances, and the relationship of the balances to the system configuration. The model can determine the efficiency of energy conversion both for an individual microturbine unit and for the entire BCHP system for various system configurations and external loads. Based on actual data from a $30-\mathrm{kW}$ microturbine, linear analysis was used to obtain an analytical relationship between the changes in the thermodynamic and hydraulic parameters of the system. The actual data show that, when the backpressure at the microturbine exhaust outlet is increased to the maximum of $7 \mathrm{in}$. wc $(0.017 \mathrm{~atm})$, the microturbine's useful power output decreases by from $3.5 \%$ at a full power setting of $30 \mathrm{~kW}$ to $5.5 \%$ at a one-third power setting $(10 \mathrm{~kW})$, while the efficiency of the unit decreases from 2.5 to $4.0 \%$, accordingly.

Tests on the microturbine were conducted at the Cooling, Heating, and Powcr Laboratory set up at the Oak Ridge National Laboratory's Buildings Technology Center. Data were collected from the microturbine at power demand settings of $30 \mathrm{~kW}$ (full load) to $10 \mathrm{~kW}$
\end{abstract}

in 5-kW increments. For each power demand setting, data measurements were taken over an entire range of microturbine exhaust backpressures. The parameters measured were engine speed, ambient air temperature, air temperature at the microturbine inlet, gas temperature at the turbine outlet, exhaust gas temperature, throttle pressure loss, flow rate of natural gas, and composition of combustion products. The mathematical model provided gas temperature before the turbine, compression rate, and air flow rate, which were determined based on the measured data. The results of these early tests and the computer-based simulation model are in very close agreement.

\section{NOMENCLATURE}

AS stoichiometric amount of air

$\mathrm{Cp} \quad$ exhaust gas heat capacity $(\mathrm{kJ} / \mathrm{kg} \cdot \mathrm{K})$

$\mathrm{Cp}_{\mathrm{a}} \quad$ air heat capacity $(\mathrm{kJ} / \mathrm{kg} \cdot \mathrm{K})$

$\mathrm{Cp}_{\mathrm{g}} \quad$ natural gas heat capacity $(\mathrm{kJ} / \mathrm{kg} \cdot \mathrm{K})$

$\mathrm{E}$ microturbine efficiency based on higher heating value of the natural gas (\%)

EA excess air (\%)

G cooling air flow rate $(\mathrm{kg} / \mathrm{s})$

$\mathrm{G}_{\mathfrak{a}} \quad$ air flow rate $(\mathrm{kg} / \mathrm{s})$

$\mathrm{G}_{\mathrm{g}} \quad$ natural gas flow rate $(\mathrm{kg} / \mathrm{s})$

$\mathrm{G}_{\mathrm{T}} \quad$ exhaust gas flow rate $(\mathrm{kg} / \mathrm{s})$

$\mathrm{k}_{\mathrm{c}} \quad \mathrm{C}_{\mathrm{p}} / \mathrm{C}_{\mathrm{v}}$ in the compressor

$\mathrm{k}_{\mathrm{T}} \quad \mathrm{C}_{\mathrm{p}} / \mathrm{C}_{\mathrm{v}}$ in the turbine

$\mathrm{M}_{\mathrm{a}} \quad$ air molecular weight $(\mathrm{kgmol})$

$\mathrm{M}_{\mathrm{T}} \quad$ gas molecular weight (kgmol)

$\mathrm{P}_{1} \quad$ turbine outlet pressure (atm)

$\mathrm{P}_{2} \quad$ turbine inlet pressure (atm)

$\mathrm{Q}_{\mathrm{G}} \quad$ combustion energy supplied to the turbine $(\mathrm{kW})$

$\mathrm{R} \quad$ universal gas constant $(\mathrm{kJ} / \mathrm{kgmol} \cdot \mathrm{K})$

SEWOR BCHP efficiency without a recuperator (\%)

SEWR BCHP efficiency with a recuperator (\%)

$\mathrm{T}_{1} \quad$ air temperature at the compressor inlet $(\mathrm{K})$

$\mathrm{T}_{3}$ air temperature after the recuperator as defined in Equation (10) (K) 


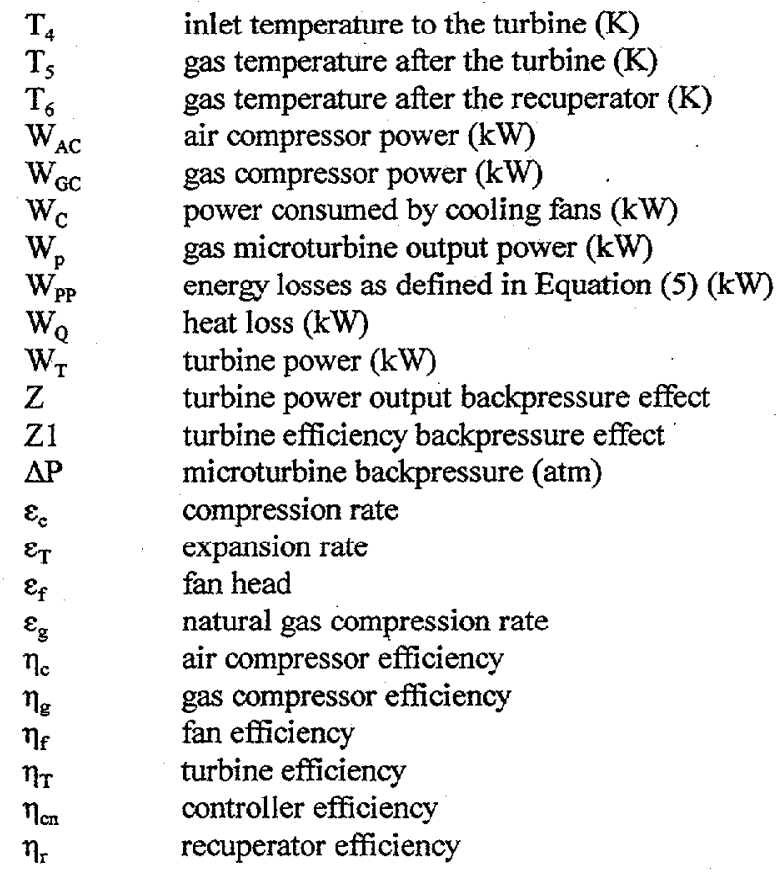

\section{INTRODUCTION}

The United States Department of Energy (DOE) has initiated a Buildings Cooling, Heating, and Power program (BCHP). ${ }^{1}$ Its aim is to focus building industry research, development, and commercialization toward on-site and near-site fuel conversion, making it possible to combine electric power generation and the optimization and integration of heating, ventilating, and air-conditioning (HVAC) systems with other innovative and energy-efficient building technologies to maximize energy efficiency, reduce energy use and emissions, increase the power capacity to critical loads by providing an option to central power generation, and improve electric power reliability and quality.

The traditional energy cycle in the United States and most other developed countries is the combustion of fossil fuels and/or the use of nuclear fuels in a large central power plant to generate electricity. Electricity is then delivered to industrial, commercial, and residential loads-such as electric air conditioners, desiccant dehumidifiers, ventilation systems, lighting, and a wide variety of household, commercial, and industrial appliances-over a high-voltage transmission and lower-voltage distribution network. More than 50 to $70 \%$ of the energy content of the fuel is lost at the power plant alone because of energy conversion inefficiencies and is discharged in the form of waste heat into the atmosphere or into adjoining lakes, rivers, and streams. Further losses occur in the electric power transmission and distribution network in the form of electric current losses $\left(I^{2} R\right)$ and power transformation losses (step-up and step-down transformer I'R and core losses).

Distributed energy resources (DER), such as microturbines, are small, modular power generation systems [1] that can be located at or

'Buildings Heating, Cooling, and Power Initiative, http://www.bchp.org/ home.html. near the site where energy is used. ${ }^{2,3}$ They include a portfolio of technologies, both supply-side and demand-side. The technologies that can most benefit BCHP include gas turbines, reciprocating engines, microturbines, and fuel cells. DER provides an opportunity for better local control and more efficient use of waste heat to boost overall efficiency and reduce emissions. The waste heat can be used as input power for heat-activated air conditioners, chillers, and desiccant dehumidifiers; to generate steam for space heating; or to provide hot water for the building laundry, kitchen, cleaning services, and/or restrooms. Making use of what is normally waste heat, BCHP systems meet a building's electrical and thermal loads with a lower input of fossil fuel, yielding resource efficiencies of 40 to $70 \%$ or more.

Great new opportunities in BCHP developed in the late 1990s with the emergence of $200-\mathrm{kW}$ fuel cells and in 1999-2000 with the emergence of $30-$ to $75-\mathrm{kW}$ microturbines. At the same time, heat recovery systems were introduced to use exhaust heat (waste heat) to heat water. The hot water could be used to drive thermally activated chillers and/or desiccant units (combined systems). The new DER systems show promise for use in multiple-occupancy buildings, hotels, hospitals, offices, and commercial establishments such as restaurants and grocery stores. However, to expand the market for DER, it is necessary to conduct research to both understand and determine the optimal system configuration for seasonal operation, especially winter versus summer operation. This research would allow the industry to provide customers with highly efficient, reliable, cost-effective, and well-integrated BCHP equipment

Within the scope of the BCHP Initiative, DOE has sponsored research on a natural-gas-fired microturbine-based $B C H P$ system at the Buildings Technology Center (BTC) of the Oak Ridge National Laboratory (ORNL). The work provides both empirical and analytical assessment of BCHP use in distributed, combined energy sources for buildings. To meet the objectives of this project, a flexible laboratory test bed was developed that allows the connection of basic BCIP functional components into various configurations. It allows study of the characteristics of each component and of the overall system under various operating modes. The configuration of this BCHP test system is shown in Figure 1. A 30-kW natural-gas-fired microturbine provides the electric power for the test bed, which feeds into the Tennessee Valley Authority (TVA) power grid via the ORNL distribution network. The test setup is designed so that the hot flue gas from the microturbine can be fed either directly to a direct-fired desiccant unit to regenerate the desiccant materials, or to a heat recovery unit (HRU) to provide hot water. The temperature of the hot flue exhaust from the microturbine ranges from 500 to $600^{\circ} \mathrm{F}(533$ to $589 \mathrm{~K}$ ), and the temperature of the exhaust leaving the HRU is anticipated to be approximately $260^{\circ} \mathrm{F}$ $(400 \mathrm{~K})$. The flue exhaust from the HRU can be either fed to the directfired desiccant unit or vented to the atmosphere. Hot water from the HRU, which will be in the range of $190-200^{\circ} \mathrm{F}(361-366 \mathrm{~K}$ ) can be fed either to the indirect-fired absorption chiller or to the indirect-fired desiccant unit. Dried and/or cooled air goes to the conditioned space or is used to cool the inlet air of the microturbine to increase its power output and efficiency.

${ }^{2} \mathrm{DOE}$ Distributed Energy Resources, http://www.eren.doe.gov/der/ whynow.html and the DER Strategic Plan, http://www.eren.doe.gov/der/ taskforce.html

${ }^{3}$ What are Distributed Energy Resources, http://www.eren.doe.gov/der/ whatis.html. 
To ensure the success of BCHP systems, the interaction of the microturbine and the HRU under steady-state modes of operation with various microturbine backpressures must be considered. One significant problem is that a heat exchanger creates hydrodynamic resistance, which results in a pressure increase at the microturbine's exhaust outlet that in turn decreases the microturbine's output power and efficiency. At the same time, hydrodynamic resistance depends on the flue gas flow rate through the working elements of the HRU (heat exchanger) and on the heat exchanger design. The greater the flue gas flow rate, the greater the hydrodynamic resistance and gas pressure from the microturbine. The increased flue gas flow rate results in a higher heat transfer coefficient and in smaller dimensions and lower weight and cost for the HRU. Thus the optimal combined operation of a microturbine and a heat exchanger depends, in a complicated way, on the microturbine's backpressure.

The activity described in this article studied baseline performance and emissions of a $30-\mathrm{kW}$ microturbine over a range of design and offdesign conditions in steady-state operating mode at various microturbine exhaust backpressures. In parallel with the experimental part of the project, a BCHP computer model was developed for baseline microturbine performance. This model will be expanded to include a variety of thermal recovery equipment, including the HRU, desiccant dehumidifier, and absorption-chiller systems. Further, the computer simulation model will be used to analyze and validate experimental data and to predict optimal operational modes for BCHP systems.

\section{EXPERIMENTAL SETUP}

The experimental setup used to collect baseline performance data on the impact of backpressure on the microturbine's exhaust is shown in Figure 2. The setup includes a 3-phase $480-\mathrm{V} / 30-\mathrm{kW}$ natural-gasfired commercially available microturbine system connected to ORNL's distribution nctwork, which is connected to the TVA grid through a 480$\mathrm{V} / 75-\mathrm{kVA}$ isolation transformer. The natural gas flow rate of the microturbine was monitored by a natural gas test meter equipped with a 0 to $200 \mathrm{in}$. wc ( 0 to $0.49 \mathrm{~atm})$ pressure gauge. The microturbine exhaust temperature is measured by a resistance temperature detector (RTD), and the inlet air temperature to the microturbine is the average from nine thermocouples mounted on the face of the microturbine unit. The backpressure on the unit is adjusted by a slide damper on the exhaust duct and is monitored by a pressure transducer $(0$ to 7.5 in. wc or 0 to $0.018 \mathrm{~atm})$. $\Lambda$ flue gas analyzer is used to monitor the oxygen, carbon monoxide $(\mathrm{CO})$, carbon dioxide $\left(\mathrm{CO}_{2}\right)$, nitrogen oxides $(\mathrm{NO}$, $\mathrm{NO}_{2}, \mathrm{NO}_{\mathrm{x}}$ ), and excess air from the microturbine. The other parameters- monitored via the manufacturer's monitoring hardware and software built into the microturbine - include the microturbine's power output; engine speed; and voltage, current, and power in each phase.

The total power output demand of the microturbine was varied in increments of $5 \mathrm{~kW}$ from $10 \mathrm{~kW}$ to $30 \mathrm{~kW}(0.33$ to 1.0 of the microturbine's nominal power output), and the backpressure ranged from 0.3 to $7 \mathrm{in}$. wc $(0.0007$ to $0.017 \mathrm{~atm})$. Series of tests on the microturbine were conducted while constant output power demand was maintained, and then while constant engine speed was maintained at various backpressures. It should be noted that because the microturbine was located outdoors, the microturbine's air inlet temperature was dictated by outdoor conditions.

\section{MATHEMATICAL MODEL}

As mentioned previously, the combined operation of a gas microturbine and other units of a BCHP system depends on the microturbine's backpressure. The exhaust gas from the gas microturbine flows through the duct and heat exchangers. To overcome the pressure losses in the heat recovery system, the gas pressure at the outlet of the microturbine has to be higher than ambient pressure by the value of these pressure losses. The increase in pressure at the outlet of the microturbine, when the rest of the microturbine parameters are the same, causes a decrease in the rate of expansion of gases in the microturbine and, consequently, a decrease in the microturbine's efficiency. The objective of this study is to define the dependence of the microturbine's power and efficiency on the exhaust backpressure. Evidently, if the backpressure is high enough, microturbine power output can decrease to the point that the efficiency becomes economically unacceptable.

To find the relationship betwecn these parameters, the following steady-state equations describing the microturbine's operation were used [2-6].

\section{Energy Balance Equation}

Microturbine output power is defined as

$$
W_{P}=W_{T}-W_{A C}-W_{G C}-W_{P P}
$$

where turbine power is defined as

$$
W_{T}=\frac{k_{T}}{k_{T}-1} \frac{R}{M_{T}}\left(G_{a}+G_{g}\right) T_{4}\left(1-\frac{1}{\frac{k_{T}-1}{\varepsilon_{T}}}\right) \eta_{T}
$$

air compressor power is defined as

$$
W_{A C}=\frac{k_{c}}{k_{c}-1} \frac{R}{M_{a}} G_{\alpha} T_{1}\left(\varepsilon_{c}^{\frac{k_{c}-1}{k_{c}}}-1\right) \frac{1}{\eta_{c}}
$$

gas compressor power is defined as

$$
W_{G C}=\frac{k_{g}}{k_{g}-1} \frac{R}{M_{g}} G_{g} T_{1}\left(\varepsilon_{g}^{\frac{k_{g}-1}{k_{g}}}-1\right) \frac{1}{\eta_{g}}
$$

and energy losses are defined as

$$
W_{P P}=W_{Q}+W_{C}
$$

where heat loss is defined as

$$
W_{Q}=G\left(T_{o t t}-T_{1}\right) C p_{a}+G_{a}\left(T_{o u t}-T_{1}\right) C p_{a} \eta_{c r}
$$




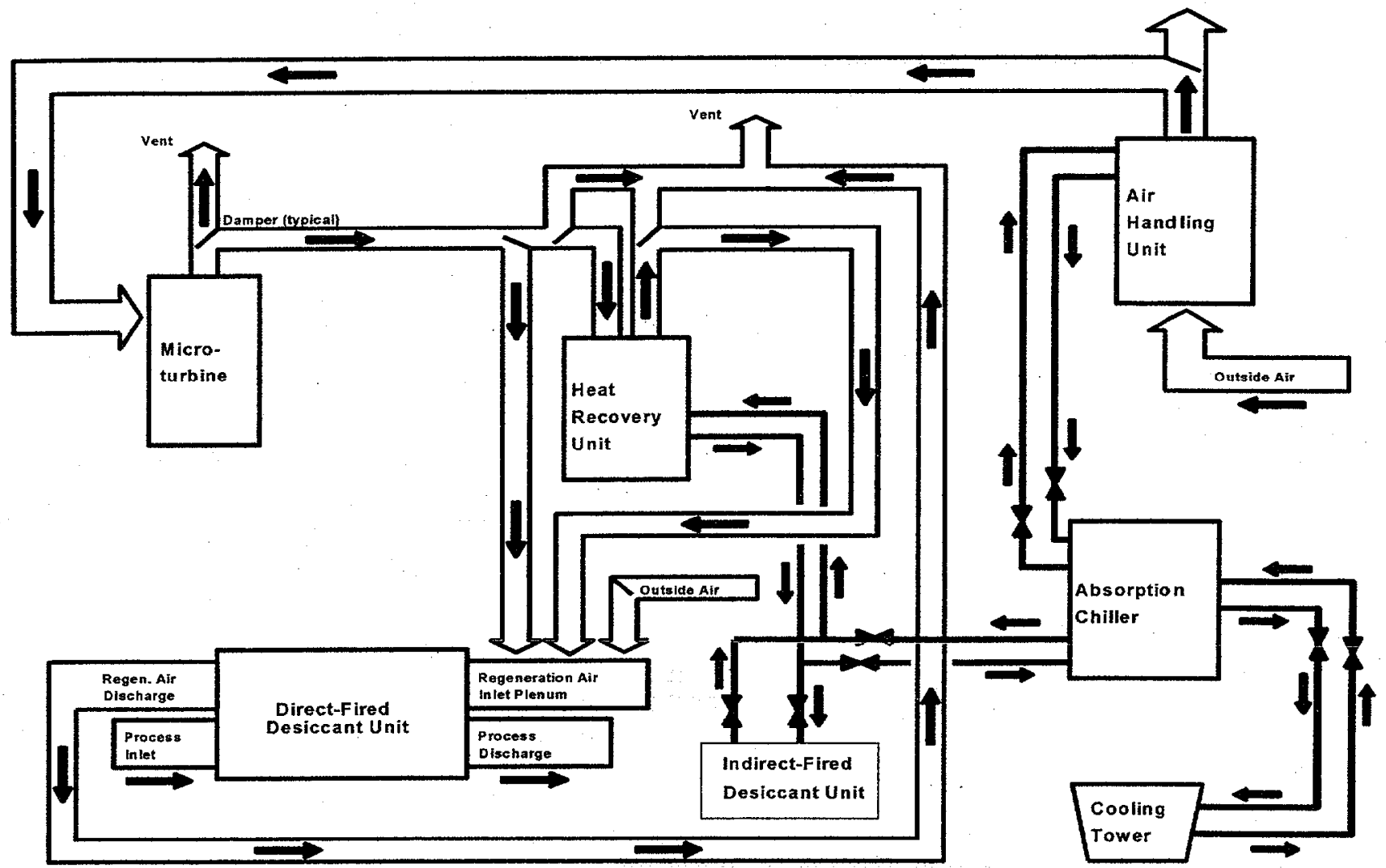

Figure 1. Flexible laboratory BCHP test bed at ORNL's BTC

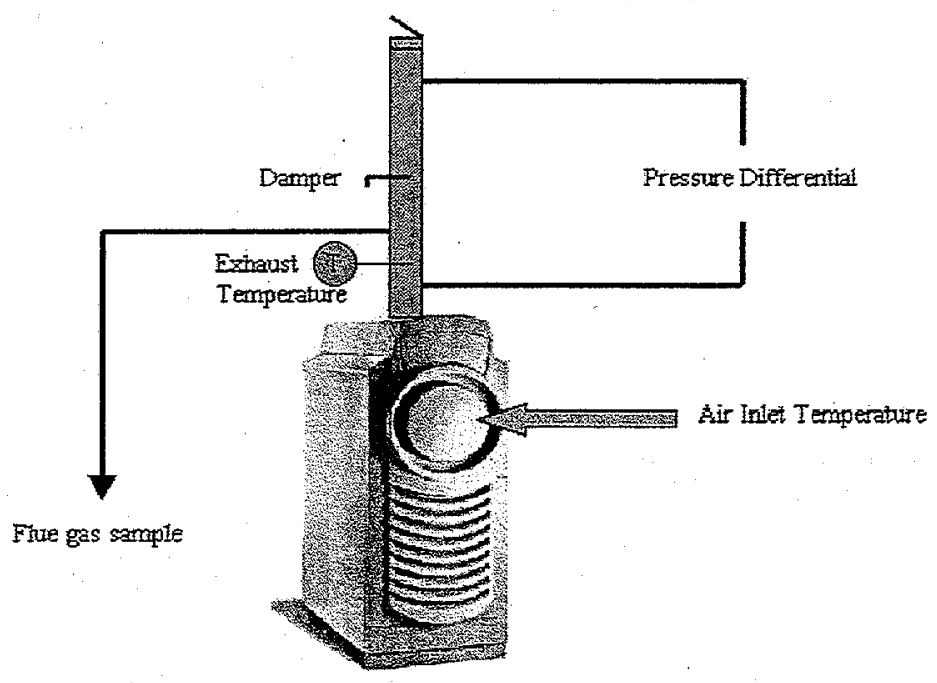

Figure 2. Experimental set-up for baseline performance testing of natural gas-fired microturbine ( $30 \mathrm{~kW}$ nominal output power) 
and power consumed by cooling fans is

$$
W_{C}=\frac{k_{a}}{k_{a}-1} G \frac{R}{M_{a}} T_{1}\left(\varepsilon_{f}^{\frac{k_{a}-1}{k_{a}}}-1\right) \frac{1}{\eta_{f}}
$$

\section{Polytropic Expansion Process Equation}

$$
T_{5}=T_{4}\left[1-\left(1-\frac{1}{\frac{k_{T}-1}{k_{T}}}\right) \eta_{T}\right]
$$

\section{Combustion Energy Balance Equation}

$$
Q_{G}=\left(G_{a}+G_{g}\right)\left(T_{4}-T_{3}\right) C p
$$

where

$$
T_{3}=T_{1}\left[1+\left(\varepsilon_{c}^{\frac{k_{c}-1}{k_{c}}}-1\right) \frac{1}{\eta_{c}}\right]+\left(T_{5}-T_{6}\right) \eta_{r} \frac{G_{g} C p_{g}}{G_{a} C p_{a}}
$$

\section{Material Balance Equation for a Combustion Chamber}

$$
G_{a}=G_{g} \cdot A S \cdot E A
$$

\section{Dependence of Expansion and Compression Rates on Backpressure}

The relationship between backpressure and pressure change in the turbine and compressor is considered for the subsonic flow case.

The turbine's expansion rate is defined as

$$
\varepsilon_{T}=\frac{P_{2}}{P_{1}}
$$

Applying linear analysis method results in

$$
\frac{\Delta \varepsilon_{T}}{\varepsilon_{T}}=\frac{\Delta P_{2}}{P_{2}}+\frac{\Delta P_{1}}{P_{1}}
$$

For subsonic flow, the pressure change at the turbine's outlet causes a similar pressure change at the turbine inlet:

$$
\Delta P_{2}=\Delta P_{1}
$$

then

$$
\frac{\Delta \varepsilon_{T}}{\varepsilon_{T}}=-\frac{\Delta P_{1}}{P_{1}}\left(1-\frac{1}{\varepsilon_{T}}\right)
$$

For the compressor, in this case,

$$
\frac{\Delta \varepsilon_{c}}{\varepsilon_{c}}=\frac{\Delta P_{1}}{P_{1}} \frac{1}{\varepsilon_{c}}
$$

On the basis of these equations and the experimental data, the set of equations representing the operation of a gas microturbine unit model were composed and solved. With this model, the following unmeasurable parameters were determined: turbine inlet temperature $\left(T_{4}\right)$, compression rate $\left(\varepsilon_{c}\right)$, expansion rate $\left(\varepsilon_{r}\right)$, exhaust gas flow rate $\left(G_{T}\right)$, air compressor efficiency $\left(\eta_{c}\right)$ and turbine efficiency $\left(\eta_{T}\right)$.

The linear analysis applied to the gas microturbine energy balance equations provides the relationship for the dependence of the changes in microturbine output power and efficiency on backpressure. Starting with Equation (1) and after manipulation,

$$
\begin{gathered}
-\frac{\Delta W_{P}}{W_{P}}=Z \frac{\Delta P}{P_{1}}+\frac{W_{C}}{W_{P}}\left(\frac{\Delta G_{a}}{G_{a}}+\frac{\Delta T_{1}}{T_{1}}\right) \\
-\frac{W_{T}}{W_{P}}\left(\frac{\Delta G_{T}}{G_{T}}+\frac{\Delta T_{4}}{T_{4}}\right)+\frac{W_{G C}}{W_{p}}
\end{gathered}
$$

$$
\left(\frac{\Delta G_{g}}{G_{g}}+\frac{\Delta T_{1}}{T_{1}}\right)+\frac{\Delta W_{P P}}{W_{P}}
$$

where

$$
G_{T}=G_{a}+G_{g}
$$

and the turbine power output backpressure effect is

$$
\begin{aligned}
& Z=\frac{k_{T}-1}{k_{T}}\left[\frac{W_{T}}{W_{P}}\left(1-\frac{1}{\varepsilon_{T}}\right) \frac{1}{\frac{k_{T}-1}{\varepsilon_{T}}-1}\right] \\
& -\frac{k_{c}-1}{k_{c}}\left[\frac{W_{C}}{W_{P}} \frac{1}{\varepsilon_{c}} \frac{\varepsilon_{c}^{\frac{k_{c}-1}{k_{c}}}}{\frac{k_{c}-1}{\varepsilon_{c}}-1}\right]-\frac{k_{g}-1}{k_{g}}\left[\frac{W_{G C}}{W_{P}} \frac{1}{\varepsilon_{g}} \frac{\frac{\varepsilon_{g}}{\frac{k_{g}-1}{k_{g}}}}{\varepsilon_{g}^{\frac{k_{g}}{k_{g}}}-1}\right]
\end{aligned}
$$

The changes in $G_{o}, G_{g}, G_{T}, T_{4}, T_{l}$, and $W_{p p}$ are assumed to be small. These parameters do not change significantly with varying microturbine backpressure at a given output power setting if the ambient temperature does not change significantly. Then

$$
\frac{\Delta G_{a}}{G_{a}}=\frac{\Delta G_{g}}{G_{g}}=\frac{\Delta G_{T}}{G_{T}}=\frac{\Delta T_{4}}{T_{4}}=\frac{\Delta T_{1}}{T_{1}}=\frac{\Delta W_{P P}}{W_{P}}=0
$$

which simplifies Equation (17) to 


$$
-\frac{\Delta W_{P}}{W_{P}}=Z \frac{\Delta P}{P_{1}}
$$

The turbine efficiency is defined as

$$
E=\frac{W_{P}}{Q_{G}}
$$

where by Equations (9) and (18) and applying linear analysis results in the following relationship, again after manipulation similar to those to obtain Equation (17).

$$
-\frac{\Delta E}{E}=\frac{\Delta P}{P_{1}} Z l-\left(\frac{\Delta T_{4}}{T_{4}}+\frac{\Delta G_{T}}{G_{T}}\right)
$$

where the turbine efficiency backpressure effect $(Z I)$ is

$$
Z 1=Z-\frac{k_{T}-1}{k_{T}}\left(\frac{1-\frac{1}{\varepsilon_{T}}}{\frac{k_{T}-1}{\varepsilon_{T}}-1}\right)
$$

If the changes in $T_{4}$ and $G_{T}$ are assumed to be small, then

$$
-\frac{\Delta E}{E}=\frac{\Delta P_{1}}{P_{1}} Z I
$$

\section{EXPERIMENTAL RESULTS}

\section{Constant Power Output Demand}

Tests were conducted at various power output demands and microturbine backpressures (damper at three different positions of fully open, 1/4 closed, and 3/8 closed). Comparing results for the same power demand in Tables 1 and 2, these tests showed that the microturbine's controller adjusts the engine speed to match its power demand setting as closely as possible, thus keeping the power output constant either with or without the backpressure present. The engine speed increased with the increase in backpressure. Additionally, Table 1 shows the reproducibility of the measured data at $20 \mathrm{~kW}$; relative power output and efficiency percentage differences are less than $0.3 \%$.

Figure 3 shows the microturbines's efficiency to be approximately $23 \%$ when it is set to the $30-\mathrm{kW}$ power demand setting (full output). However, when a lower power demand setting is used -for example, one- third output $(10 \mathrm{~kW})$ - the efficiency of the unit drops significantly from approximately $23 \%$ to approximately $18 \%$. It should be noted that the efficiency is based on the higher heating value (HHV) of natural gas. The HHVs were obtained daily from the East Tennessee Natural Gas-Customer Information Access System. The efficiency based on the lower heating value (LHV) of natural gas would be approximately $10 \%$ higher than the one based on HHV or approximately $25 \%$ at full output $(30 \mathrm{~kW})$. It should be noted that the efficiencies quoted by microturbine manufacturers usually are based on the LHV.

The microturbine's exhaust temperature was found to be around $500^{\circ} \mathrm{F}(533 \mathrm{~K})$ at the unit's maximum power demand setting $(30 \mathrm{~kW})$. As expected, the exhaust temperature increased with increasing turbine air inlet temperature. The flue gas results showed the $\mathrm{NO}_{\mathrm{x}}$ to be very low at all power output demands ( $25 \mathrm{ppm}$ or less) with $18.5 \%$ to $19.1 \%$ oxygen content. The $\mathrm{CO}_{2}$ concentrations were found to be between $1.5 \%$ at full power setting $(30 \mathrm{~kW})$, and $1.1 \%$ at one-third setting $(10 \mathrm{~kW})$. The CO concentration consistently peaked at 127 and $134 \mathrm{ppm}$ when the microturbine was set to the $20-\mathrm{kW}$ power output setting (Tables 1 and 2).

\section{Constant Engine Speed}

Another series of tests was conducted while the microturbine was maintained at constant engine speed and varying backpressure for each nominal power output. Due to the space limitations within this article, Table 3 shows only the results at full power of $30 \mathrm{~kW}$. Figure 4 shows the effect of turbine backpressure on the microturbine unit. Tables 1 and 2 showed that the engine speed increased with the backpressure to maintain a constant power output with identical efficiencies. However, at a constant engine speed, the average turbine efficiency dropped by less than $2 \%$ and the average turbine power output decreased by less than $6 \%$ of the values with damper fully open.

\section{Estimation of BCHP Overall System Efficiency}

Figure 5 shows the exhaust flow rates at various microturbine power output levels. These flow rates were calculated from the measured natural gas flow rates and excess air. Results show a close agreement between the estimated exhaust gas flow rate and the exhaust flow rate provided by the microturbine manufacturer at the full output setting of 30-kW. Figure 6 shows the turbine efficiency (measured) and the BCHP system efficiency (calculated via the mathematical model). The BCHP system efficiency was estimated for the microturbine with and without a recuperator. The BCHP efficiency with a recuperator is defined as

$$
S E W R=\frac{\left[W_{P}+G_{T} C p\left(T_{6}-400\right)\right]}{Q_{G}} .
$$

The BCHP efficiency without a recuperator is defined as

$$
\text { SEWOR }=\frac{\left[W_{P}+G_{T} C p\left(T_{5}-400\right)\right]}{\left[Q_{G}+G_{T} C p\left(T_{5}-T_{6}\right)\right]} .
$$

The recuperator is used for internal heat recovery of the heat rejected by the turbine to the cycle and for increasing the turbine efficiency from approximately $15 \%$ (simple cycle without recuperator) to approximately $23 \%$ (cycle with recuperator). However, the deployment of a recuperator as a BCHP system component causes a decrease in the quantity of heat that is exhausted by the microturbine to drive other heat recovery components assuming full demand for heat. As a result, the total quantity of exhaust heat is decreased, and the total efficiency of a BCHP system drops. It should be noted that Equations (26) and (27) are based on the venting of $260^{\circ} \mathrm{F}(400 \mathrm{~K})$ exhaust gas to the atmosphere.

Figure 6 shows potential improvement in BCHP overall system efficiency with the elimination of the microturbine recuperator. It should be noted that the recuperator represents approximately $25-30 \%$ of the overall microturbine cost [7]. 
Table 1. Capstone 30-kW microturbine with damper fully open

\begin{tabular}{|c|c|c|c|c|c|c|c|c|c|c|c|c|}
\hline $\begin{array}{l}\text { Power } \\
\text { demand } \\
\text { setting } \\
\text { (W) }\end{array}$ & $\begin{array}{l}\text { Power } \\
\text { output } \\
\text { (W) }\end{array}$ & $\begin{array}{l}\text { Efficiency } \\
(\mathrm{HHV})^{*}\end{array}$ & $\begin{array}{l}\mathrm{T}_{\text {air inlet }} \\
\left({ }^{\circ} \mathrm{F}\right)\end{array}$ & $\begin{array}{l}\mathrm{T}_{\text {cxhaust }} \\
\left({ }^{\circ} \mathrm{F}\right)\end{array}$ & $\begin{array}{l}\text { Engine } \\
\text { speed } \\
\text { (RPM) }\end{array}$ & $\begin{array}{c}\Delta \mathrm{P} \\
\text { (in. wc) }\end{array}$ & $\begin{array}{l}\text { No } \\
\text { (ppm) }\end{array}$ & $\begin{array}{l}\mathrm{NO}_{x} \\
(\mathrm{ppm})\end{array}$ & $\begin{array}{l}\mathrm{CO}_{2} \\
(\%)\end{array}$ & $\begin{array}{c}\mathrm{CO} \\
(\mathrm{ppm})\end{array}$ & $\begin{array}{c}\mathrm{O}_{2} \\
(\%)\end{array}$ & $\begin{array}{l}\text { Voltage } \\
\text { phases } \\
\text { A, B, C } \\
\text { (V) }\end{array}$ \\
\hline 30000 & $27678 \pm 135$ & $0.2313 \pm 0.0011$ & $27.6 \pm 1.2$ & $494.4 \pm 0.5$ & $88980 \pm 183$ & $0.34 \pm 0.09$ & 0 & 0 & 1.4 & 16 & 18.5 & $\begin{array}{l}289,288, \\
288\end{array}$ \\
\hline 25000 & $24963 \pm 87$ & $0.2265 \pm 0.0008$ & $29.3 \pm 0.9$ & $484.0 \pm 0.4$ & $86048 \pm 135$ & $0.28 \pm 0.07$ & 0 & $\overline{0}$ & 1.4 & $\overline{33}$ & 18.6 & $\begin{array}{l}289,288, \\
288\end{array}$ \\
\hline 20000 & $19987 \pm 110$ & $0.2178 \pm 0.0012$ & $29.2 \pm 0.9$ & $457.9 \pm 0.6$ & $80377 \pm 131$ & $0.23 \pm 0.07$ & 0 & $\overline{0}$ & 1.3 & 130 & 18.7 & $\begin{array}{l}287,286, \\
285\end{array}$ \\
\hline 20000 & $20037 \pm 97$ & $0.2172 \pm 0.0011$ & $33.7 \pm 0.5$ & $463.0 \pm 0.3$ & $81264 \pm 60$ & $0.22 \pm 0.05$ & $\overline{0}$ & 0 & 1.3 & 127 & 18.7 & $\begin{array}{l}289,287, \\
287\end{array}$ \\
\hline 15000 & $15040 \pm 86$ & $0.2044 \pm 0.0012$ & $35.4 \pm 0.7$ & $437.3 \pm 0.4$ & $75076 \pm 69$ & $0.16 \pm 0.05$ & 24 & 24 & 1.2 & 10 & 18.9 & $\begin{array}{l}287,286, \\
285\end{array}$ \\
\hline 10000 & $9994 \pm 71$ & $0.1798 \pm 0.0013$ & $35.4 \pm 0.8$ & $407.7 \pm 0.5$ & $67461 \pm 87$ & $0.11 \pm 0.04$ & 19 & 19 & 1.1 & 17 & 19.1 & $\begin{array}{l}286,285, \\
284\end{array}$ \\
\hline
\end{tabular}

"Efficiency is based on natural gas higher heating value.

Table 2. Capstone 30-kW microturbine with damper 3/8 closed

\begin{tabular}{|c|c|c|c|c|c|c|c|c|c|c|c|c|}
\hline $\begin{array}{c}\text { Power } \\
\text { demand } \\
\text { setting } \\
(\mathrm{W})\end{array}$ & $\begin{array}{c}\text { Power } \\
\text { output } \\
(\mathrm{W})\end{array}$ & $\begin{array}{c}\text { Efficiency } \\
(\mathrm{HHV})^{*}\end{array}$ & $\begin{array}{c}\mathrm{T}_{\text {ai inkt }} \\
\left({ }^{\circ} \mathrm{F}\right)\end{array}$ & $\begin{array}{c}\mathrm{T}_{\text {exhaust }} \\
\left({ }^{\circ} \mathrm{F}\right)\end{array}$ & $\begin{array}{c}\text { Engine } \\
\text { speed } \\
(\mathrm{RPM})\end{array}$ & $\begin{array}{c}\Delta \mathrm{P} \\
(\mathrm{in} . \mathrm{wc})\end{array}$ & $\begin{array}{c}\mathrm{NO} \\
(\mathrm{ppm})\end{array}$ & $\begin{array}{c}\mathrm{NO}_{\mathrm{x}} \\
(\mathrm{ppm})\end{array}$ & $\begin{array}{c}\mathrm{CO}_{2} \\
(\%)\end{array}$ & $\begin{array}{c}\mathrm{CO} \\
(\mathrm{ppm})\end{array}$ & $\begin{array}{c}\mathrm{O}_{2} \\
(\%)\end{array}$ & $\begin{array}{c}\text { Voltage } \\
\text { phases } \\
\mathrm{A}, \mathrm{B}, \mathrm{C} \\
(\mathrm{V})\end{array}$ \\
\hline 30000 & $28646 \pm 235$ & $0.2256 \pm 0.0019$ & $37.9 \pm 1.6$ & $517.2 \pm 1.8$ & $92956 \pm 365$ & $7.34 \pm 0.17$ & 0 & 0 & 1.4 & 11 & 18.5 & $\begin{array}{l}290,289, \\
288\end{array}$ \\
\hline 25000 & $25031 \pm 85$ & $0.2212 \pm 0.0008$ & $40.1 \pm 0.9$ & $500.3 \pm 0.9$ & $88772 \pm 162$ & $6.14 \pm 0.10$ & 0 & 0 & 1.4 & 43 & 18.5 & 289,288, \\
287
\end{tabular}

"Efficiency is based on natural gas higher heating value.

\section{Results of Mathematical Model}

Figures 7 and 8 show the turbine power output backpressure effect $(Z)$ and the turbine efficiency backpressure effect $(Z I)$ as functions of turbine inlet temperature $\left(T_{4}\right)$ and expansion rate $\left(\varepsilon_{c}\right)$ for the case of subsonic gas flow. Results show that the dependence of the turbine efficiency on backpressure is not as strong as that of the turbine output power. An increase in backpressure while other conditions are kept the same causes the temperature after the turbine to increase and, consequently, the air in the recuperator to heat to a higher temperature, which results in a decrease in fuel consumption. In all cases, the influence of backpressure decreases with increasing turbine inlet temperature. The dependence of the backpressure effects on the expansion rate shows a minimum in the range of 3.5 to 6.0 at the turbine inlet temperature of $1120 \mathrm{~K}$ or $1556^{\circ} \mathrm{F}$.

During the experiments, measurements were taken with the exhaust backpressure changing from 0.3 to 7 in. wc $(0.0007$ to $0.017 \mathrm{~atm}$ ) to determine the dependence of output power and efficiency on backpressure. Although the values of inlet turbine temperature $\left(T_{4}\right)$, compressor inlet temperature $\left(T_{l}\right)$, air flow $\left(G_{a}\right)$, and exhaust gas flow $\left(G_{T}\right)$ were not constant, they did not change significantly (less than $5 \%$ ) during these tests. However, the influence of these parameters on Equations (17) and (23) is considerable. In order to find the direct dependence of these parameters on backpressure, the measured values for these parameters were used to deduce corrections in Equations (17) and (23). Then these corrections were subtracted from measured values of $\Delta \mathrm{Wp} / \mathrm{Wp}$ and $\Delta \mathrm{E} / \mathrm{E}$, correspondingly. Thus corrected experimental data were compared with model calculations based on constant temperatures and flow rates (Figure 9). Please note that in Figure 9 only the maximum backpressure was used to illustrate the maximum difference between the theory and the measurements for relative changes in power and efficiency. As shown, the corrected experimental and calculated data agree quite well. Further, the data show that the output power losses (decrease in power output) due to backpressure range from $3.5 \%$ for full output $(30 \mathrm{~kW})$ to $5.5 \%$ for one-third power 


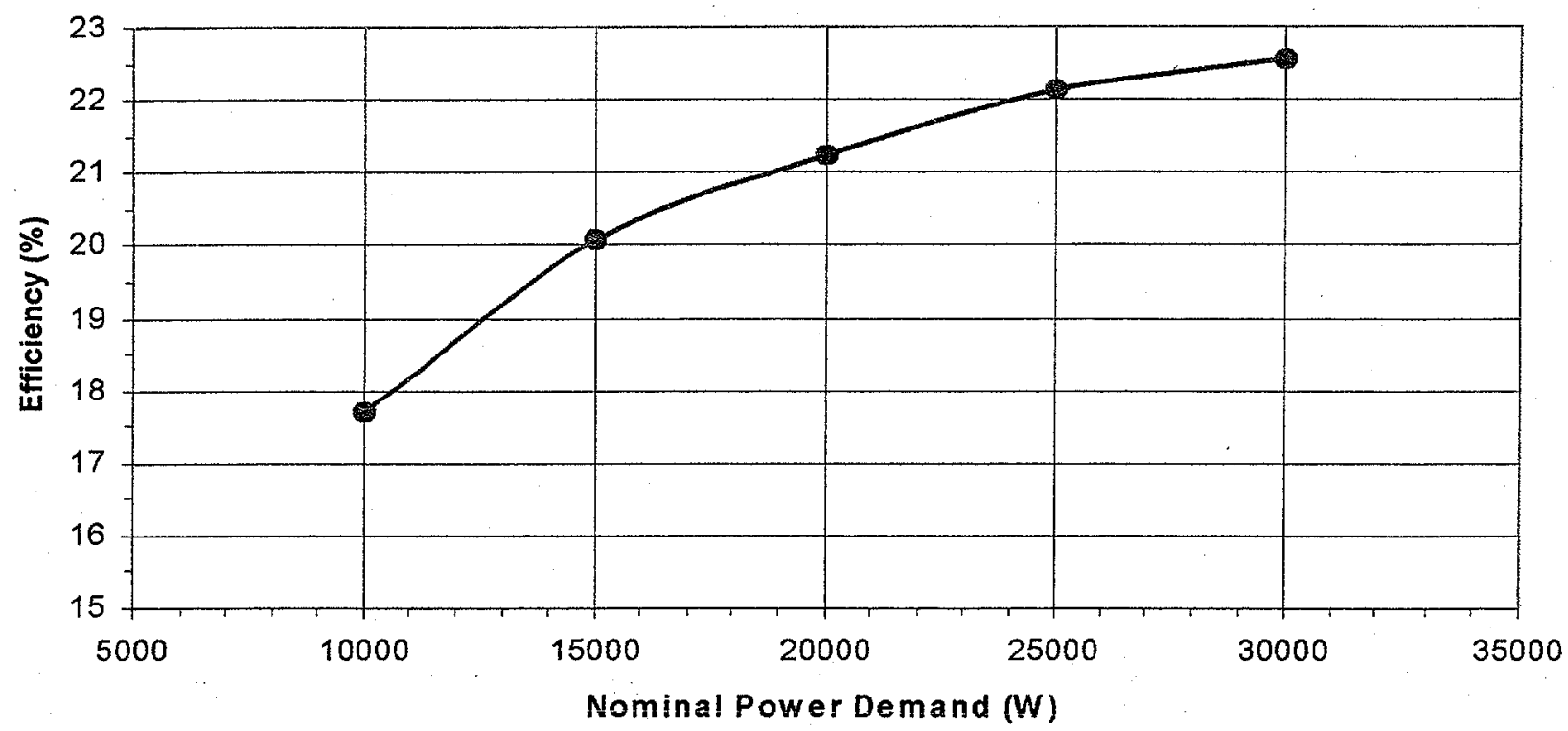

Figure 3. Efficiency of $30 \mathrm{~kW}$ gas microturbine as a function of nominal power demand with damper $3 / 8$ closed

Table 3. Microturbine performance with approximately constant engine speed (30-kW nominal output demand setting) and varying turbine backpressure

\begin{tabular}{|c|c|c|c|c|c|c|c|c|c|c|c|}
\hline $\begin{array}{c}\text { Power } \\
\text { output } \\
\text { (W) }\end{array}$ & $\begin{array}{c}\text { Efficiency } \\
(H H V)^{8}\end{array}$ & $\begin{array}{c}T_{\text {air inlet }} \\
\left({ }^{\circ} \mathrm{F}\right)\end{array}$ & $\begin{array}{c}T_{\text {exhaust }} \\
\left({ }^{\circ} \mathrm{F}\right)\end{array}$ & $\begin{array}{c}\text { Engine } \\
\text { speed } \\
\text { (RPM) }\end{array}$ & $\begin{array}{c}\Delta \mathrm{P} \\
\text { (in. wc) }\end{array}$ & $\begin{array}{c}\text { NO } \\
\text { (ppm) }\end{array}$ & $\begin{array}{c}\mathrm{NO}_{\mathrm{x}} \\
(\mathrm{ppm})\end{array}$ & $\begin{array}{l}\mathrm{CO}_{2} \\
(\%)\end{array}$ & $\begin{array}{c}\mathrm{CO} \\
(\mathrm{ppm})\end{array}$ & $\begin{array}{c}\mathrm{O}_{2} \\
(\%)\end{array}$ & $\begin{array}{c}\text { Voltage } \\
\text { phases } \\
A, B, C \\
(V)\end{array}$ \\
\hline $28064 \pm 142$ & $0.2256 \pm 0.0011$ & $\begin{array}{c}34.3 \pm 1.5 \\
-\end{array}$ & $505.2 \pm 1.5$ & $90504 \pm 252$ & $0.33 \pm 0.09$ & 0 & 0 & 1.3 & 19 & 18.8 & $\begin{array}{l}288,287, \\
287\end{array}$ \\
\hline $27926 \pm 147$ & $0.2269 \pm 0.0012$ & $32.6 \pm 1.7$ & $504.9 \pm 1.3$ & $90799 \pm 271$ & $0.34 \pm 0.09$ & 0 & 0 & 1.5 & 14 & 18.5 & $\begin{array}{l}288,287, \\
286\end{array}$ \\
\hline $27984 \pm 139$ & $0.2269 \pm 0.0011$ & $31.6 \pm 1.4$ & $504.0 \pm 1.1$ & $90867 \pm 306$ & $1.88 \pm 0.09$ & 0 & 0 & 1.5 & 14 & 18.5 & $\begin{array}{l}288,287, \\
286\end{array}$ \\
\hline $27594 \pm 152$ & $0.2248 \pm 0.0012$ & $33.9 \pm 1.6$ & $506.1 \pm 1.6$ & $90902 \pm 296$ & $4.50 \pm 0.17$ & 0 & 0 & 1.5 & 17 & 18.4 & $\begin{array}{l}289,288 \\
287\end{array}$ \\
\hline $26884 \pm 182$ & $0.2226 \pm 0.0015$ & $38.4 \pm 1.7$ & $508.0 \pm 0.9$ & $91055 \pm 281$ & $5.78 \pm 0.16$ & 0 & 0 & 1.5 & 28 & 18.5 & $\begin{array}{l}288,287, \\
286\end{array}$ \\
\hline $26489 \pm 133$ & $0.2213 \pm 0.0011$ & $39.8 \pm 1.5$ & $508.9 \pm 1.4$ & $90974 \pm 292$ & $6.99 \pm 0.13$ & 0 & 0 & 1.4 & 31 & 18.5 & $\begin{array}{l}288,287, \\
287\end{array}$ \\
\hline
\end{tabular}

Efficiency is based on natural gas higher heating value.

output $(10 \mathrm{~kW})$, while the efficiency losses (decrease in efficiency) range from 2.5 to $4.0 \%$, correspondingly.

\section{CONCLUSIONS}

The BCHP experimental setup at ORNL's BTC, consisting of a $30-\mathrm{kW}$ microturbine and thermal recovery components, was used to conduct a series of backpressure tests on the microturbine. Tests were conducted both with and without backpressure and with the microturbine's power demand set at outputs of $30 \mathrm{~kW}$ (fill load) to $10 \mathrm{~kW}$ (one-third load) in $5-\mathrm{kW}$ increments. For each power demand setting, measurements were taken over an entire range of turbine backpressures from 0.3 to 7 in wc $(0.0007$ to $0.017 \mathrm{~atm})$. In parallel with the experiments, a BCHP mathematical model was developed to describe basic thermodynamic and hydraulic processes in the system, heat and material balances, and the relationship of the balances to the system configuration. The model was used to determine the efficiency 


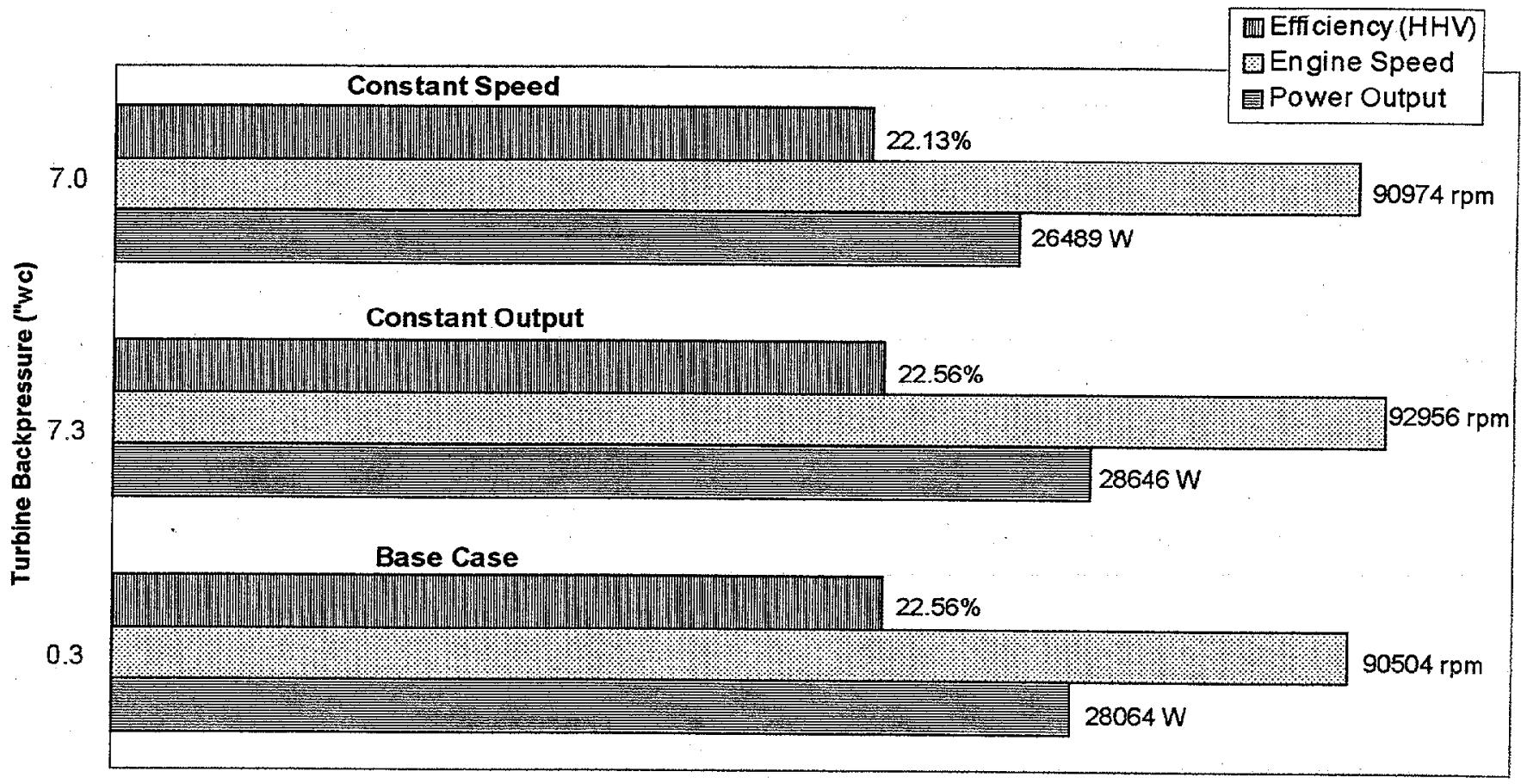

Figure 4. Effect of turbine backpressure on the performance of the unit

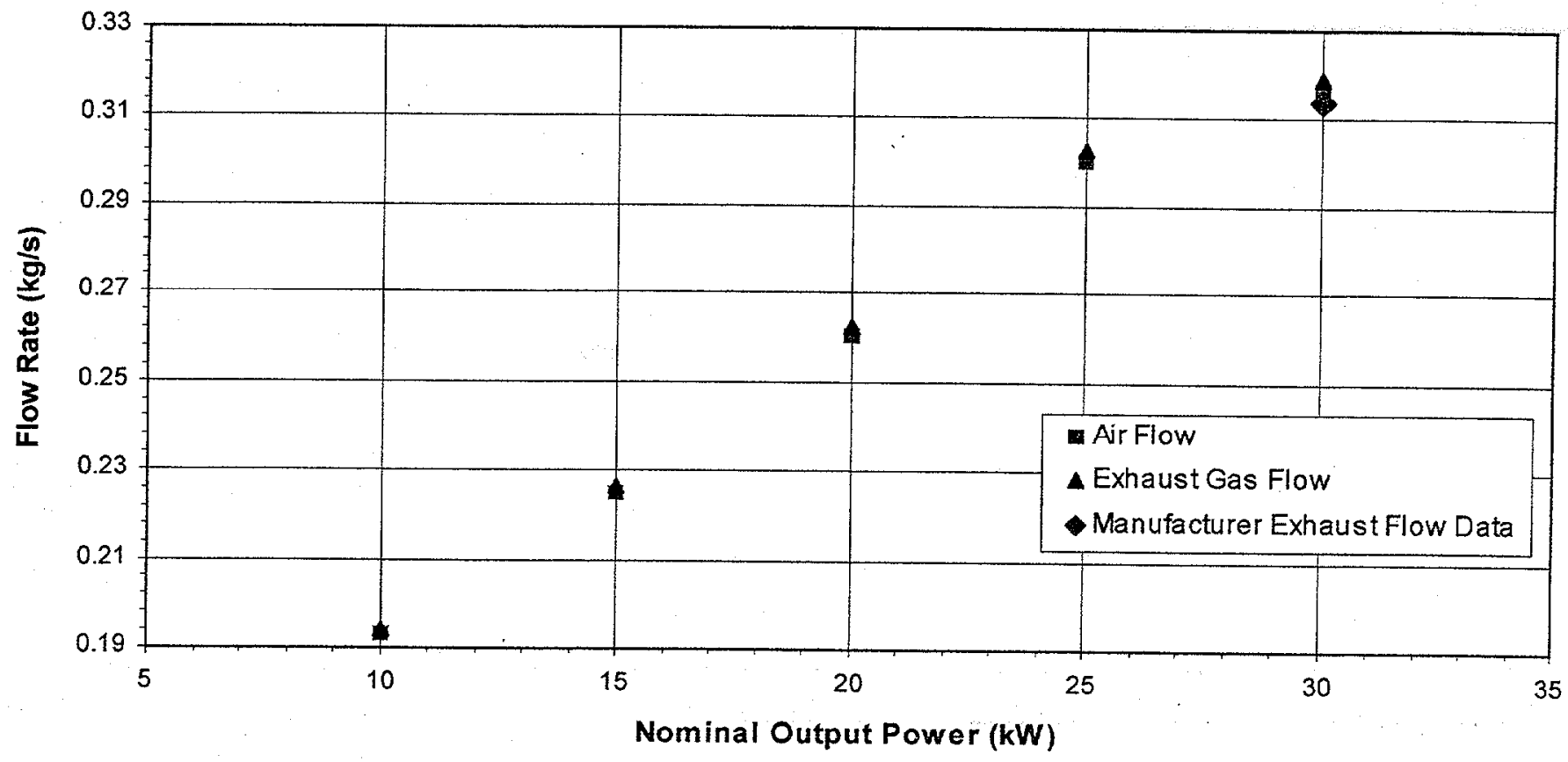

Figure 5. Exhaust flow rates as a function of nominal power output. 


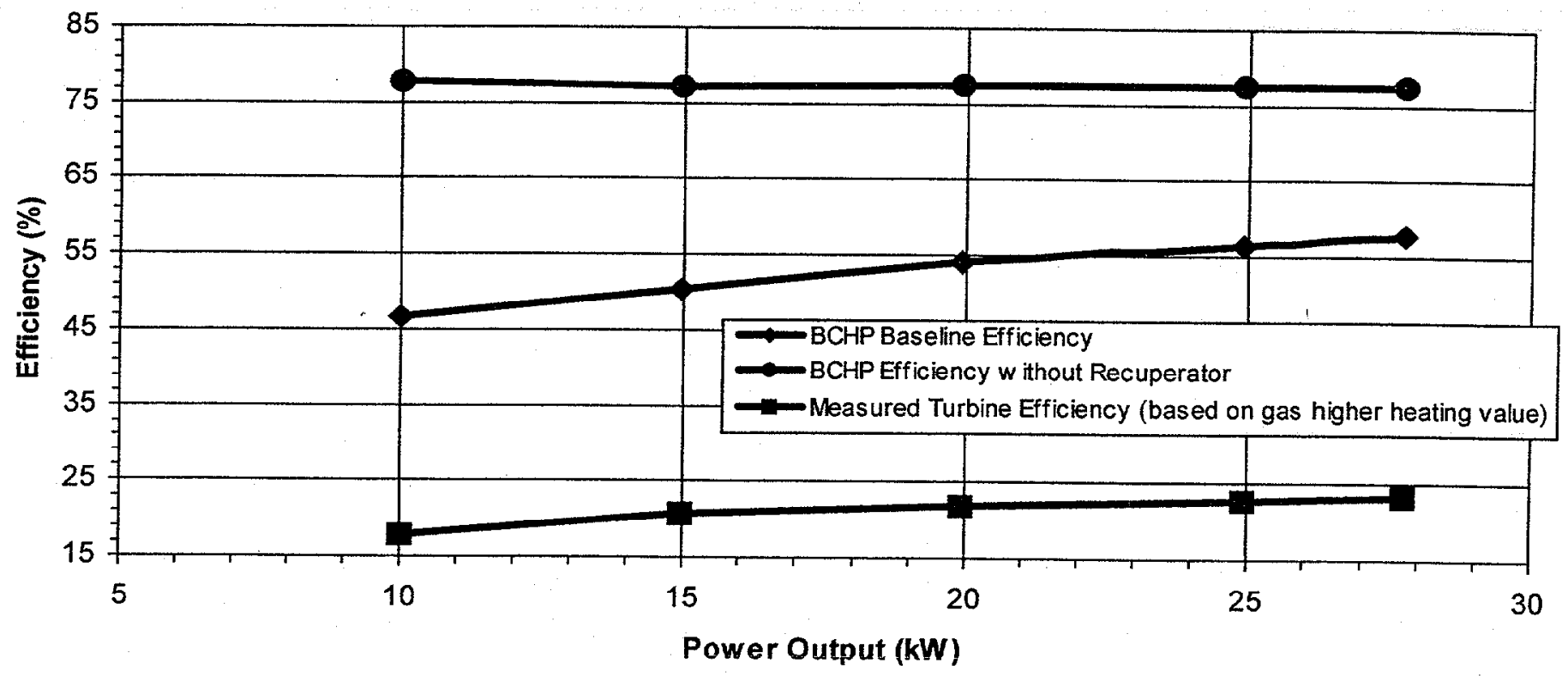

Figure 6. Turbine and BCHP overall system efficiencies.

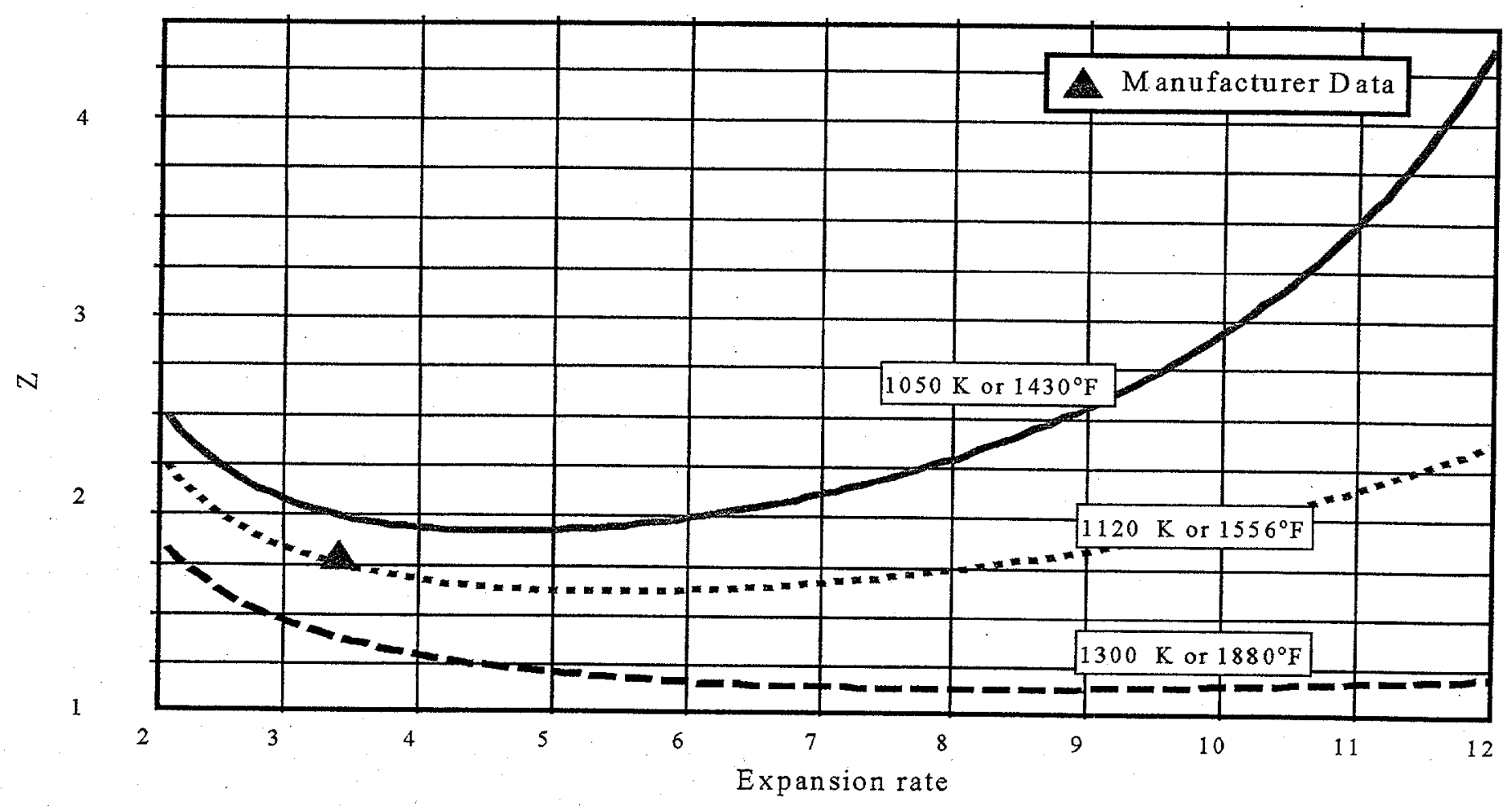

Figure 7. Turbine power backpressure effect $(Z)$ as functions of turbine inlet temperature and expansion rate for the case of subsonic gas flow 


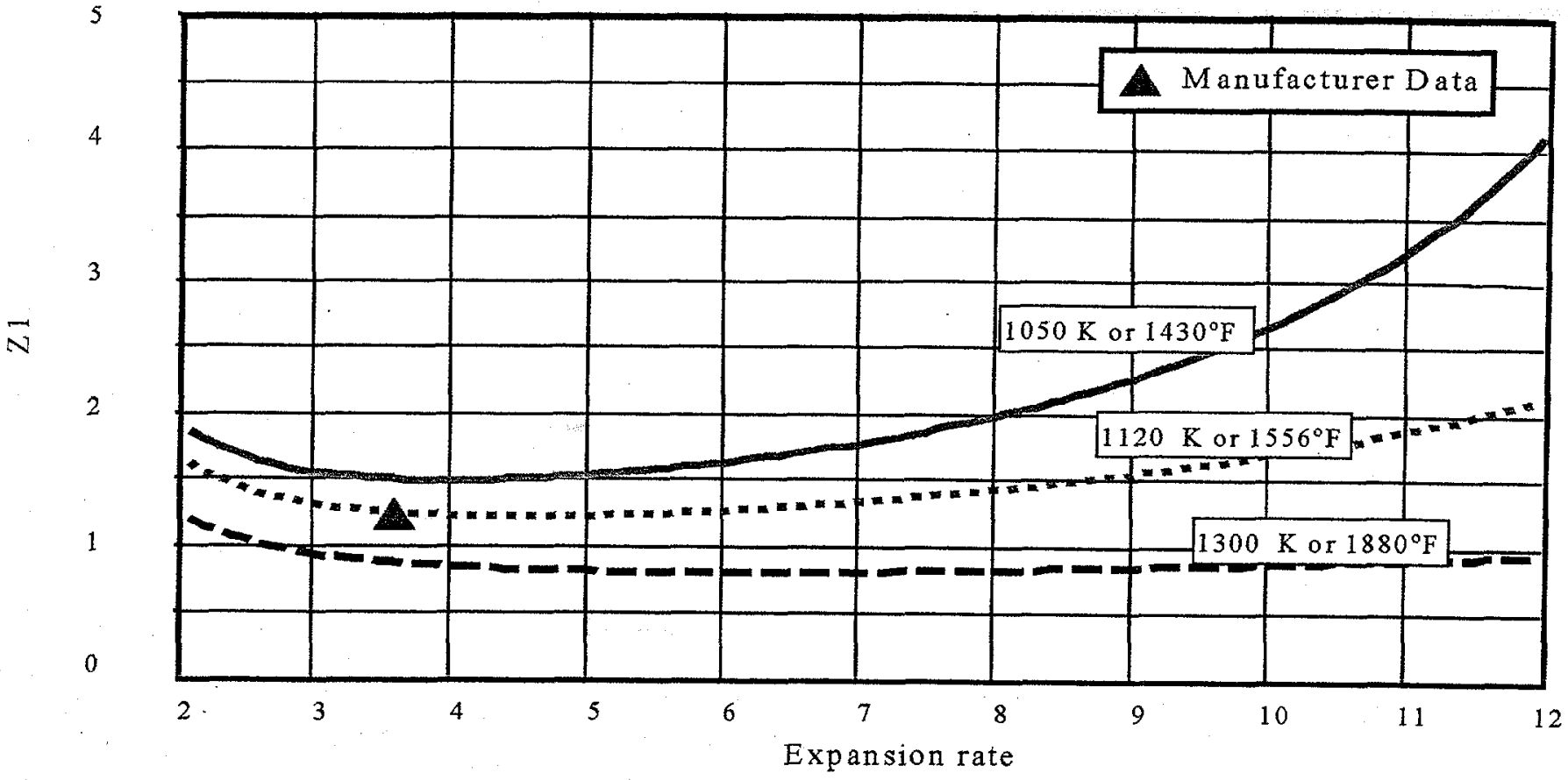

Figure 8. Turbine efficiency backpressure effect $(\mathrm{Z} 1)$ as functions of turbine inlet temperature and expansion rate for the case of subsonic gas flow

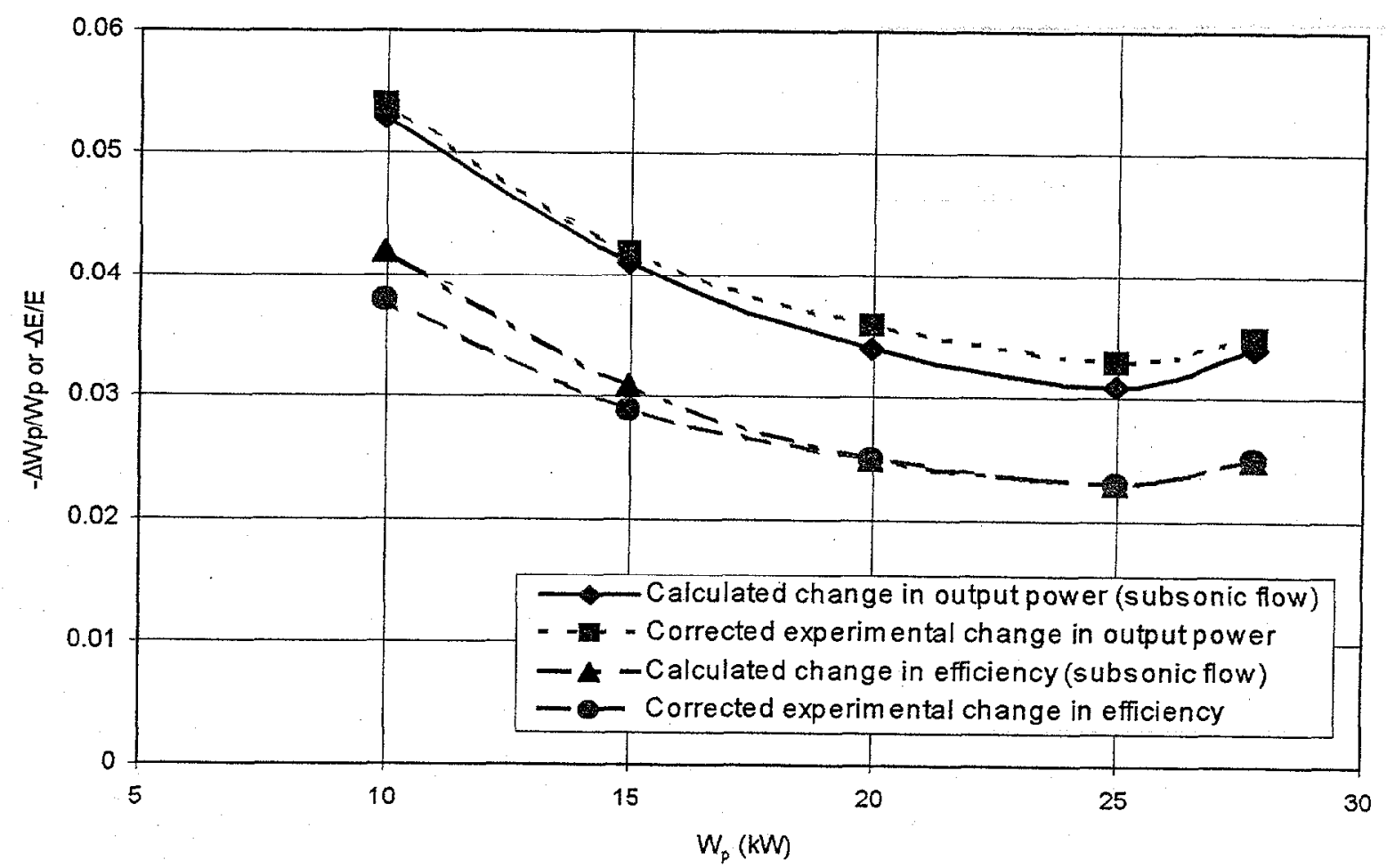

Figure 9. Experimental and calculated relative changes of microturbine output power and efficiency at maximum relative backpressure as a function of power output 
of energy conversion for an individual microturbine unit and for the entire BCHP system using various system configurations and external loads. Linear analysis was used to obtain an analytical relationship between the changes in thermodynamic and hydraulic parameters of the BCFIP system. Experimental results showed that the average turbine efficiency dropped by less than $2 \%$ and the average turbine power output decreased by less than $6 \%$ of the values with damper fully open, at a constant engine speed. It was found that the corrected experimental and calculated data agree quite well. Further, the data show that the output power losses (decrease in power output) due to backpressure range from $3.5 \%$ for $30 \mathrm{~kW}$ to $5.5 \%$ for $10 \mathrm{~kW}$, while the efficiency losses (decrease in efficiency) range from 2.5 to $4.0 \%$, correspondingly.

\section{ACKNOWLEDGMENTS}

The authors would like to thank DOE for supporting this work. This work was conducted by ORNL under DOE contract DE-AC0500OR22725 with UT-Battelle, LLC.

\section{REFERENCES}

1. U.S. Department of Energy 2000, Strategic Plan For Distributed Energy Resources, Office of Energy Efficiency and Renewable Energy and Office of Fossil Energy, Washington, D.C.

2. Reid, R. C., Prausnitz, J. M., and Sherwood, T. K., 1977, The Properties of Gases and Liquids, McGraw-Hill, New York.

3. Spiewak, S. A., 1987, Cogeneration and Small Power Production Mamual, Fairmont Press, Liburn, Georgia.

4. Electric Power Research Institute, 1983, Gas Turbine Evaluation (GATE) Computer Program, EPRI Research Project AP-2871CCM, Palo Alto, California.

5. AGARD-LS-198, Mathematical Model of Gas Turbine Engines and Their Components, 1994.

6. Bejan, A., 1996, Thermal Design and Optimization, John Wiley and Sons, New York.

7. McDonald, C. F., "Low-Cost Recuperator Concept For Microturbine Applications," 2000, in Proceedings of ASME TURBOEXPO 2000, ASME paper 2000-GT-167, Munich, Germany. 